\title{
Differentiation of normal and giant Vicia faba populations of the stem nematode Ditylenchus dipsaci: agreement between RAPD and phenotypic characteristics
}

\author{
MAGALI ESQUIBET, SADIA BEKAL, PHILIPPE CASTAGNONE-SERENO†, \\ J EAN-PIERRE GAUTHIER, ROGER RIVOAL \& GEORGES CAUBEL* \\ Institut National de la Recherche Agronomique, Laboratoire de Zoologie, Rennes, BP 29, F 35653 Le Rheu Cedex \\ and †Laboratoire de Biologie des Invertébrés, BP 2078, F 06606 Antibes Cedex, France
}

\begin{abstract}
Two main race groups of the stem nematode, Ditylenchus dipsaci, attack Vicia faba. The aim of this work was to evaluate random amplified polymorphic DNA (RAPD) as a source of markers for race identification and variability analysis of $D$. dipsaci. Thirteen populations of $D$. dipsaci were tested and one population of both D. myceliophagus and D. destructor as outgroup species. Sufficient levels of variation were detected to allow a clear distinction between the two D. dipsaci groups. This result was in agreement with the characterization based on morphological differences among races and on the type of faba bean disease symptoms. The intraspecific variation within $D$. dipsaci populations associated with $V$. faba was low and no strong correlation could be found between the geographical origin and molecular or morphological characterization. RAPDs are a powerful tool for identification of $D$. dipsaci races and/or populations.
\end{abstract}

Keyw ords: Ditylenchus dipsaci, morphometrics, RAPD, Vicia faba.

\section{Introduction}

The stem nematode, Ditylenchus dipsaci (Kühn) Filipjev, is an obligatory polyphagous endoparasite, which can infest over 500 species of plants. Extensive intraspecific variation has been demonstrated in the host range of this nematode: this led to the distinction of 30 races (Sturhan \& Brzeski, 1991). The reliability of the host races in $D$. dipsaci has been discussed by Janssen (1994). Among the 30 races, two main groups are recognized as pathogenic to Vicia faba: the first one contains normal races with different host ranges, the second is represented by a giant race (Debray \& Maupas, 1896). Differentiated from the normal races by size and pathogenicity towards V.faba (Ait Ighil, 1983; Hooper, 1984), the giant race has a limited host range (Sturhan \& Brzeski, 1991). It is a serious pest of faba bean in the subtropical semi-arid regions of many Mediter-

*Correspondence. E-mail: caubel@rennes.inra.fr ranean countries (Sikora \& Greco, 1990). According to Triantaphyllou \& Hirschmann (1980), this race has a haploid chromosome number $(n=22-24)$ higher than the normal race and probably represents polyploid or aneuploid forms derived from ancestral Ditylenchus $(n=12)$. Attempts to hybridize diploid and tetraploid populations pathogenic to Vicia faba produced viable hybrids (Ladigyna, 1982). Furthermore, Ait Ighil (1983) and Sturhan (1983) showed that these $F_{1}$ were never fertile, and thus the giant race should be recognized as a sibling species. Triantaphyllou \& Hirschmann (1980) have suggested that this species is presently in a state of active evolution and speciation. Neither polyclonal antibodies (Gibbins \& Grandison, 1968) nor enzyme electrophoresis (Hussey \& Krusberg, 1971) could provide reliable tools for identifying host races. More recently, molecular probes specific to $D$. dipsaci have been developed, but they proved to be ineffective for the distinction of races (Palmer et al., 1991). RFLP analysis of PCR-amplified ribosomal 
sequences allowed the distinction between normal and giant races of $D$. dipsaci, but no other intraspecific differences could be detected (Wendt et al., 1993).

The objectives of the present work were to study the intraspecific variability in a set of $D$. dipsaci populations attacking $V$. faba by classical (size, symptomatology) and molecular (RAPD-PCR) methods, in order to infer relationships between the normal and giant races. For comparison, D. destructor and D. myceliophagus, plant-parasitic and mycophagous nematodes, respectively, have been included as outgroup species, related to $D$. dipsaci.

\section{Materials and methods}

\section{Nematode populations}

Thirteen populations of $D$. dipsaci originating from different geographical areas and one population of each of $D$. destructor and D. myceliophagus were used in this study. Their main characteristics are reported in Table 1. To limit the influence of host plant on body size, all the $D$. dipsaci populations were reared on V.faba cv. Aguadulce according to Caubel \& Leclercq (1989a). Ten-day-old plants were inoculated with 100 fourth-stage juveniles (J4) on the first emerging axillary bud and kept in a growth chamber at $\approx 15^{\circ} \mathrm{C}$. For the following analysis, nematodes were extracted from either fresh or dried Aguadulce plant tissues. Ditylenchus myceliophagus was maintained monoxically on the fungus Agaricus bisporus, growing on malt-agar medium $45 \mathrm{~g} \mathrm{~L}^{-1}$ (Cayrol,

Table 1 Origins of Ditylenchus populations studied

\begin{tabular}{lll}
\hline Species & Code & Origin \\
\hline D. dipsaci & TIA & Tiaret, Algeria \\
D. dipsaci & AIL & Beaumont, France \\
D. dipsaci & AP & Le Rheu, France \\
D. dipsaci & COR & Corlay, France \\
D. dipsaci & LR & Le Rheu, France \\
D. dipsaci & ARI & Ariana, Tunisia \\
D. dipsaci & BEJ & Beja, Tunisia \\
D. dipsaci & SAD & El Bab, Syria \\
D. dipsaci & BOU & Boulaouane, Morocco \\
D. dipsaci & CHE & Chefchaouen, Morocco \\
D. dipsaci & DAR & Dar Bouazza, Morocco \\
D. dipsaci & DCH & Dar Chaoui, Morocco \\
D. dipsaci & LKH & El Khyaita, Morocco \\
D. myceliophagus & MYC & Antibes (INRA), France \\
D. destructor & DES & Saint Pol, France \\
\hline
\end{tabular}

1970). Ditylenchus destructor was extracted from bulbous iris collected from fields.

\section{Symptoms and morphological measurements analysis}

Nine weeks after the inoculation, classical symptoms of plant infection were scored for each population of D. dipsaci, to determine the race phenotype (Caubel \& Leclercq, 1989b): swelling and shortening of the inoculated bud or necrotic lesion of the bud and stem were associated with the giant or the normal races, respectively. The body length of females, males and $\mathrm{J} 4$ was measured on fixed nematodes mounted in FA 4:1 (formaldehyde 4\%, glacial acetic acid 1\% in water) (Goodey, 1963). For each population and developmental stage, measurements were made on 30 individuals. Data were subjected to separate analysis of variance, using sAs software (sAS Institute, 1988). Means were classified according to the Newman-Keuls test at $P \leq 0.05$.

\section{DNA extraction}

For each population 5000-50000 nematodes were rinsed in distilled water, pelleted in a microcentrifuge and ground in a pestle. Total genomic DNA was extracted according to the phenol-chloroform procedure (Sambrook et al., 1989). Following ethanol precipitation, DNA was resuspended in TE buffer [0.01 M Tris (pH 8.0), 0.001 м EDTA (ethylene diamine tetraacetic acid)] to a final concentration of $5 \mathrm{ng} \mu \mathrm{L}^{-1}$ and stored at $-20^{\circ} \mathrm{C}$.

\section{DNA amplification and electrophoresis}

Nineteen random decamer oligonucleotides of the Operon kit G (Operon Technologies, Atlanta, CA) were tested, and used according to the manufacturer's directions. RAPD reactions were carried out in a $12.5 \mu \mathrm{L}$ final volume containing $10 \mathrm{ng}$ of genomic DNA; $2.5 \mu \mathrm{mol}$ of primer; $4.4 \mathrm{nmol} \mathrm{MgCl}_{2}$; dATP, dCTP, dGTP and dTTP (Boehringer) each at $100 \mu \mathrm{M}$ final concentration; $0.5 \mathrm{U}$ Taq polymerase (Appligene) and $1 \times$ Taq incubation buffer. Each reaction was overlaid with a droplet of mineral oil to prevent evaporation. Amplifications were performed in a 480 Perkin Elmer thermal cycler. The cycling programme was: (i) $94^{\circ} \mathrm{C}, 1 \mathrm{~min}$; (ii) 40 cycles of $94^{\circ} \mathrm{C}, 1 \mathrm{~min} ; 40^{\circ} \mathrm{C}, 1 \mathrm{~min}$; and $72^{\circ} \mathrm{C}, 2 \mathrm{~min}$; and (iii) a final incubation of $72^{\circ} \mathrm{C}, 10 \mathrm{~min}$. Amplification products were stored at $4^{\circ} \mathrm{C}$ before use and separated by electrophoresis in $1.5 \%$ agarose gels in TBE buffer ( $89 \mathrm{~mm}$ Tris, $89 \mathrm{~mm}$ boric acid and $2 \mathrm{~mm}$ 
EDTA, pH 8.0) at a constant current of $200 \mathrm{~mA}$ for about $2 \mathrm{~h}$. Products were visualized by ethidium bromide staining $\left(0.5 \mu \mathrm{g} \mathrm{mL}^{-1}\right)$ and examined under ultraviolet (UV) light. Marker VI (Boehringer) was used as the molecular weight marker.

\section{RAPD data analysis}

Data from RAPD patterns were scored for the presence (1) or the absence (0) of similar bands in each nematode population. Only reproducible bands were taken into account, and band-sharing was analysed in a pair-wise comparison using the method described by Nei \& Li (1979). Similarity $(S)$ was calculated according to the equation:

$S=2 N_{a b} /\left(N_{a}+N_{b}\right)$,

where $N_{a}$ is the number of bands in genotype $a, N_{b}$ is the number of bands in genotype $b$ and $N_{a b}$ is the number of bands shared by genotypes $a$ and $b$. Similarity values could theoretically range from 0 (no shared bands) to 1 (all bands common to both genotypes). The coefficient of dissimilarity $D(D=1-S)$ was then used to construct a dendrogram using the unweighted pair group method with averaging (UPGMA), performed with the PHYLIP package version 3.5c (Felsenstein, 1993). Node accuracy for branches of the resulting tree was estimated by the bootstrap approach (Felsenstein, 1985).

\section{Results}

\section{Symptoms and morphological measurements}

Among the 13 stem nematode populations tested, eight populations were scored as giant (BOU, CHE, DAR, SAD, COR, LR, LKH and ARI) and five as normal (TIA, AIL, DCH, BEJ and AP) by the pathologies induced (Table 2). The comparison of female length means showed five significantly different groups. The three groups $\mathrm{ab}, \mathrm{c}$ and $\mathrm{d}$ included eight populations with mean lengths ranging from 1649 to $1987 \mu \mathrm{m} \quad$ (average $=1832 \mu \mathrm{m}$ ). These populations were those previously classified as giant according to plant symptoms. Lengths of females from the two last groups (e and f) ranged from 1289 to $1410 \mu \mathrm{m}$ (average $=1325 \mu \mathrm{m}$ ) corresponded to the five populations which caused necrotic lesions specific to a normal race. Analysis of male size showed the same grouping of populations, the significantly larger nematodes with an average length of $1704 \mu \mathrm{m}$ and the normal $D$. dipsaci with an average length of $1291 \mu \mathrm{m}$. Very similar results were obtained comparing $\mathrm{J} 4$ lengths, with the exception of the population ARI. Although still significant, differences between J4 length were smaller than those observed for

Table 2 Phenotypic characterization of giant $(\mathrm{G})$ and normal $(\mathrm{N})$ races of the Ditylenchus dipsaci populations

\begin{tabular}{|c|c|c|c|c|c|}
\hline \multirow[b]{2}{*}{ Code } & \multirow{2}{*}{$\begin{array}{l}\text { Symptoms } \\
\text { of attacks* }\end{array}$} & \multicolumn{3}{|c|}{ Length $(\mu \mathrm{m}) \dagger$} & \multirow{2}{*}{$\begin{array}{c}\text { Race } \\
\text { phenotype }\end{array}$} \\
\hline & & Female & Male & $\mathrm{J} 4$ & \\
\hline BOU & $\mathrm{s}$ & 1987 (145) a & 1820 (142) a & 1213 (88) b & G \\
\hline $\mathrm{CHE}$ & $\mathrm{s}$ & $1939(150) \mathrm{ab}$ & $1816(98)$ a & 1173 (89) bc & G \\
\hline DAR & s & $1934(101) a b$ & $1860(106) \mathrm{a}$ & 1156 (113) bc & G \\
\hline SAD & s & $1894(83) \mathrm{ab}$ & $1724(81) \mathrm{b}$ & 1141 (87) bc & $\mathrm{G}$ \\
\hline COR & $\mathrm{s}$ & $1801(97) \mathrm{c}$ & $1546(88) \mathrm{c}$ & 1283 (127) a & $\mathrm{G}$ \\
\hline LR & s & $1789(166) \mathrm{c}$ & 1747 (71) b & $1186(87) \mathrm{bc}$ & $\mathrm{G}$ \\
\hline LKH & $\mathrm{s}$ & $1661(137) \mathrm{d}$ & $1548(126) \mathrm{c}$ & $1205(84) \mathrm{ab}$ & $\mathrm{G}$ \\
\hline ARI & $\mathrm{s}$ & 1649 (174) d & 1567 (101) c & $1082(106) \mathrm{ad}$ & $\mathrm{G}$ \\
\hline TIA & ne & $1410(96) \mathrm{e}$ & $1260(102) \mathrm{e}$ & 1041 (64) de & $\mathrm{N}$ \\
\hline AIL & ne & $1308(49) \mathrm{f}$ & $1299(90) \mathrm{e}$ & 1003 (69) de & $\mathrm{N}$ \\
\hline $\mathrm{DCH}$ & ne & $1302(84) \mathrm{f}$ & 1265 (101) e & 1067 (72) d & $\mathrm{N}$ \\
\hline BEJ & ne & 1298 (81) f & $1282(76) \mathrm{e}$ & 995 (50) be & $\mathrm{N}$ \\
\hline $\mathrm{AP}$ & ne & 1289 (101) f & $1356(108) \mathrm{d}$ & $1089(147) \mathrm{d}$ & $\mathrm{N}$ \\
\hline
\end{tabular}

*Swelling (s) and necrosis (ne) scored on Vicia faba cv. Aguadulce.

$\dagger$ Means (standard deviations) followed by the same letter, in each column, are not significantly different at $\mathrm{P} \leq 0.05$ according to the Newman-Keuls test 
males and females (average length $=1048 \mu \mathrm{m}$ for the normal race and $1180 \mu \mathrm{m}$ for the giant race).

\section{Amplification of nematode DNA}

The DNA extraction procedure from 5000 nematodes produced enough DNA to perform about 70 PCR reactions. After an initial screening, six primers (OPG-01, OPG-07, OPG-08, OPG-09, OPG-10, OPG-15) were discarded, because they produced unreadable and/or unreproducible amplification patterns. The patterns obtained after amplification of the DNA from the 15 Ditylenchus genotypes with the remaining 13 primers revealed more than 330

(a)

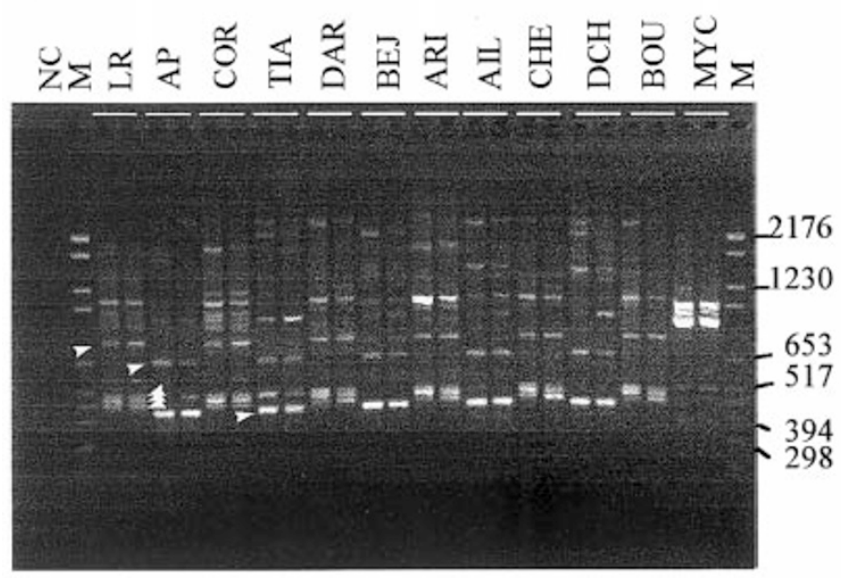

(c)

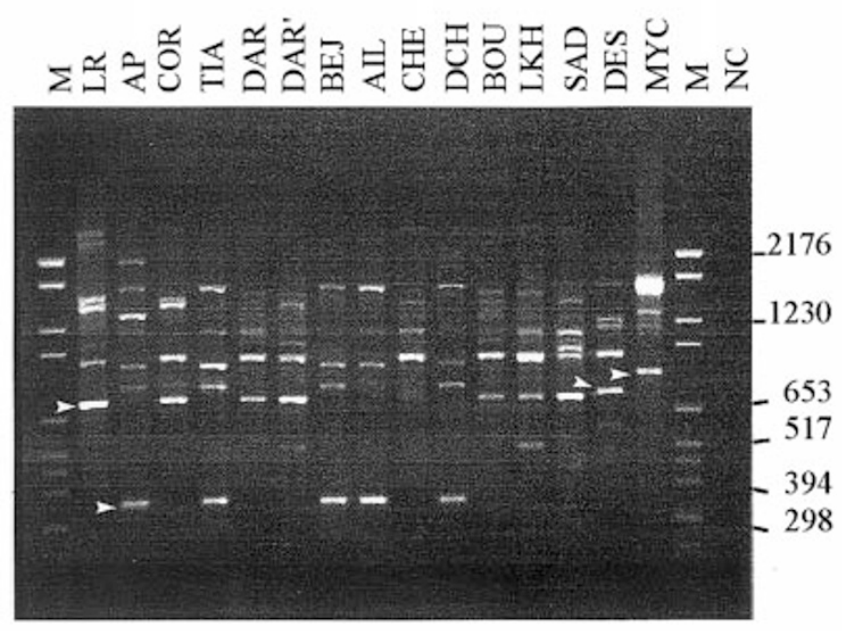

bands. As examples, the DNA polymorphisms detected with OPG-11 and OPG-13 are given in Fig. 1. Only fragments with a high intensity and no doubt as to their presence or absence in the three RAPD replicates were taken into account. Thus, of the 18 bands obtained in Fig. 1(a,b), eight bands were discarded. With each primer, six to 16 bands from 0.2 to $2.0 \mathrm{~kb}$ were scored and a total of 124 reproducible fragments were counted (Table 3 ). As no band was common to all the stem nematode populations tested, it was not possible to select markers specific to the D. dipsaci species. However, whatever the primer used, differences between the normal and the giant populations were readily

(b)

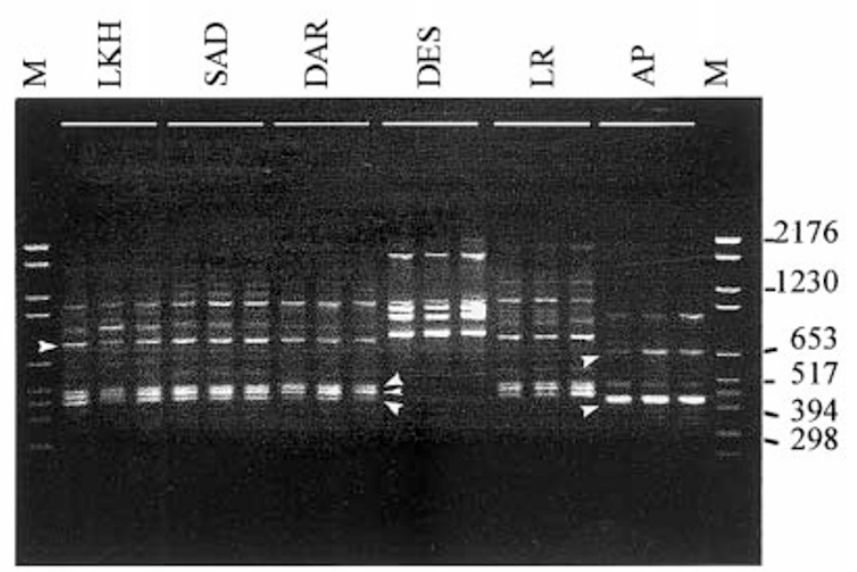

Fig. 1 RAPD amplification patterns obtained from Ditylenchus populations using (a) primer OPG-13 with two replicate lanes for each population; (b) primer OPG-13 with three replicate lanes for each of six other populations; (c) primer OPG-11. Arrows point to several representative polymorphisms. Molecular size values (kb) were estimated from molecular size markers (M). NC is the negative control. Population codes are given in Table 1.

(C) The Genetical Society of Great Britain, Heredity, 81, 291-298. 
observed. A total of 25 markers were specific to the giant race populations, and a total of 15 markers characterized the normal populations. Nevertheless, four primers (OPG-06, OPG-16, OPG-17 and OPG-18) yielded markers strictly specific to the giant race. In addition, four primers revealed

Table 3 Number of markers specific to the giant and normal races of Ditylenchus dipsaci produced per primer

\begin{tabular}{llrcr}
\hline \multicolumn{2}{l}{ Primers } & & & \\
\cline { 1 - 2 } Code & \multicolumn{1}{c}{ 5' to 3' $^{\prime}$} & Total & $\begin{array}{c}\text { Giant } \\
\text { race }\end{array}$ & $\begin{array}{c}\text { Normal } \\
\text { race }\end{array}$ \\
\hline OPG-02 & GGCACTGAGG & 15 & 2 & 1 \\
OPG-03 & GAGCCCTCCA & 13 & 3 & 2 \\
OPG-04 & AGCGTGTCTG & 9 & 1 & 3 \\
OPG-05 & CTGAGACGGA & 7 & 1 & 1 \\
OPG-06 & GTGCCTAACC & 11 & 4 & 0 \\
OPG-11 & TGCCCGTCGT & 8 & 1 & 2 \\
OPG-12 & CAGCTCACGA & 5 & 1 & 2 \\
OPG-13 & CTCTCCGCCA & 10 & 3 & 2 \\
OPG-14 & GGATGAGACC & 6 & 1 & 1 \\
OPG-16 & AGCGTCCTCC & 8 & 1 & 0 \\
OPG-17 & ACGACCGACA & 10 & 1 & 0 \\
OPG-18 & GGCTCATGTG & 6 & 1 & 0 \\
OPG-19 & GTCAGGGCAA & 16 & 5 & 1 \\
Total & & 124 & 25 & 15 \\
\hline
\end{tabular}

markers specific to some D. dipsaci populations (OPG-02 to LR and CHE, OPG-03, OPG-16 and OPG-19 to ARI, BEJ and AIL, respectively).

Based on the patterns observed, a matrix of similarity indices was constructed (Table 4) and subjected to the UPGMA analysis. The $13 \mathrm{D}$. dipsaci populations fell into two separate clusters, in perfect agreement with their race status (Fig. 2). These two clusters were fully supported by the bootstrap analysis (bootstrap value $>50 \%$ ). The two outgroup species, D. myceliophagus and D. destructor, appeared closer to the normal race than to the giant race cluster, but only one isolate of $D$. myceliophagus and $D$. destructor was used and the grouping was not supported by the bootstrap analysis.

\section{Discussion}

Populations of the stem nematode, developing on $V$ faba, can be separated into two main biological groups, the giant and the normal races. Until now, the differentiation of these two groups was mostly based on comparative analysis of body length, chromosome number and type of symptoms caused in faba bean. In the present study, the RAPD approach was evaluated, in parallel with classical methods, for its ability to distinguish giant and normal races. Comparison of adult length showed

Table 4 Similarity indexes $(\times 100)$ between Ditylenchus populations obtained with 13 primers and based on shared DNA fragments

DIP*

\begin{tabular}{|c|c|c|c|c|c|c|c|c|c|c|c|c|c|c|}
\hline & \multicolumn{8}{|c|}{ Giant race } & \multicolumn{5}{|c|}{ Normal races } & \\
\hline & LR & $\mathrm{COR}$ & ARI & SAD & $\mathrm{BOU}$ & DAR & CHE & LKH & AP & AIL & TIA & BEJ & $\mathrm{DCH}$ & \\
\hline lrCOR & 94 & & & & & & & & & & & & & \\
\hline ARI & 92 & 91 & & & & & & & & & & & & \\
\hline SAD & 96 & 96 & 93 & & & & & & & & & & & \\
\hline BOU & 96 & 93 & 93 & 94 & & & & & & & & & & \\
\hline DAR & 96 & 93 & 93 & 94 & 100 & & & & & & & & & \\
\hline $\mathrm{CHE}$ & 95 & 92 & 95 & 93 & 96 & 96 & & & & & & & & \\
\hline LKH & 97 & 94 & 94 & 96 & 99 & 99 & 97 & & & & & & & \\
\hline $\mathrm{AP}$ & 9 & 12 & 9 & 9 & 9 & 9 & 8 & 9 & & & & & & \\
\hline AIL & 12 & 15 & 12 & 12 & 12 & 12 & 11 & 12 & 86 & & & & & \\
\hline TIA & 8 & 12 & 8 & 9 & 8 & 8 & 8 & 8 & 91 & 84 & & & & \\
\hline BEJ & 6 & 9 & 6 & 6 & 6 & 6 & 6 & 6 & 86 & 77 & 86 & & & \\
\hline $\mathrm{DCH}$ & 3 & 6 & 3 & 3 & 3 & 3 & 3 & 3 & 89 & 81 & 89 & 90 & & \\
\hline MYC & 3 & 3 & 6 & 3 & 3 & 3 & 6 & 3 & 10 & 10 & 10 & 11 & 11 & \\
\hline DES & 9 & 9 & 9 & 9 & 9 & 9 & 8 & 9 & 12 & 12 & 15 & 13 & 13 & 7 \\
\hline
\end{tabular}

MYC DES

*DIP, D. dipsaci; MYC, D. myceliophagus; DES, D. destructor. 
that populations, scored as giant according to plant reactions, were always significantly larger than the normal. RAPD banding patterns which easily separated these giant populations from the normal ones demonstrate a very strong agreement between the molecular and the classical approaches. The RAPD patterns are theoretically not affected by epigenetic variations, which are more likely to occur when studying morphometry or host-parasite interactions (Barraclough \& Blackith, 1962). This suggests that RAPD-PCR should be considered as a powerful method for the accurate differentiation between giant and normal races within D. dipsaci populations pathogenic to faba bean.

The $D$. dipsaci giant race was differentiated as a sibling species (Sturhan, 1971) because it is cytogenetically different from the other races (tetraploid vs. diploid) and it did not produce fertile progeny when it was crossed with one of the diploid races (Ait Ighil, 1983; Sturhan, 1983). A recent restriction digestion analysis following PCR amplification of the ribosomal internal transcribed spacer (ITS) supported the hypothesis of sibling species by yielding fragments diagnostic for the giant populations, including our LR population, compared to a set of different diploid races (Wendt et al., 1993). In the RAPD work presented here, the giant and normal populations of $D$. dipsaci were easily isolated, as no bands were common to both groups of races. Moreover, the tree topology clearly defined four groups when all $D$. dipsaci populations were computed with the outgroup species, D. myceliophagus and D. destructor. A principal coordinate analysis (not shown) calculated from the similarity matrix confirmed the separation of these four groups. Thus, the divergence between the two groups of $D$. dipsaci races seemed to be as great as between the three species. Such a clear separation between populations from the giant and the normal races provides new support for the sibling species hypothesis.

The RAPD patterns showed intraspecific variation among the two groups of $D$. dipsaci races which was

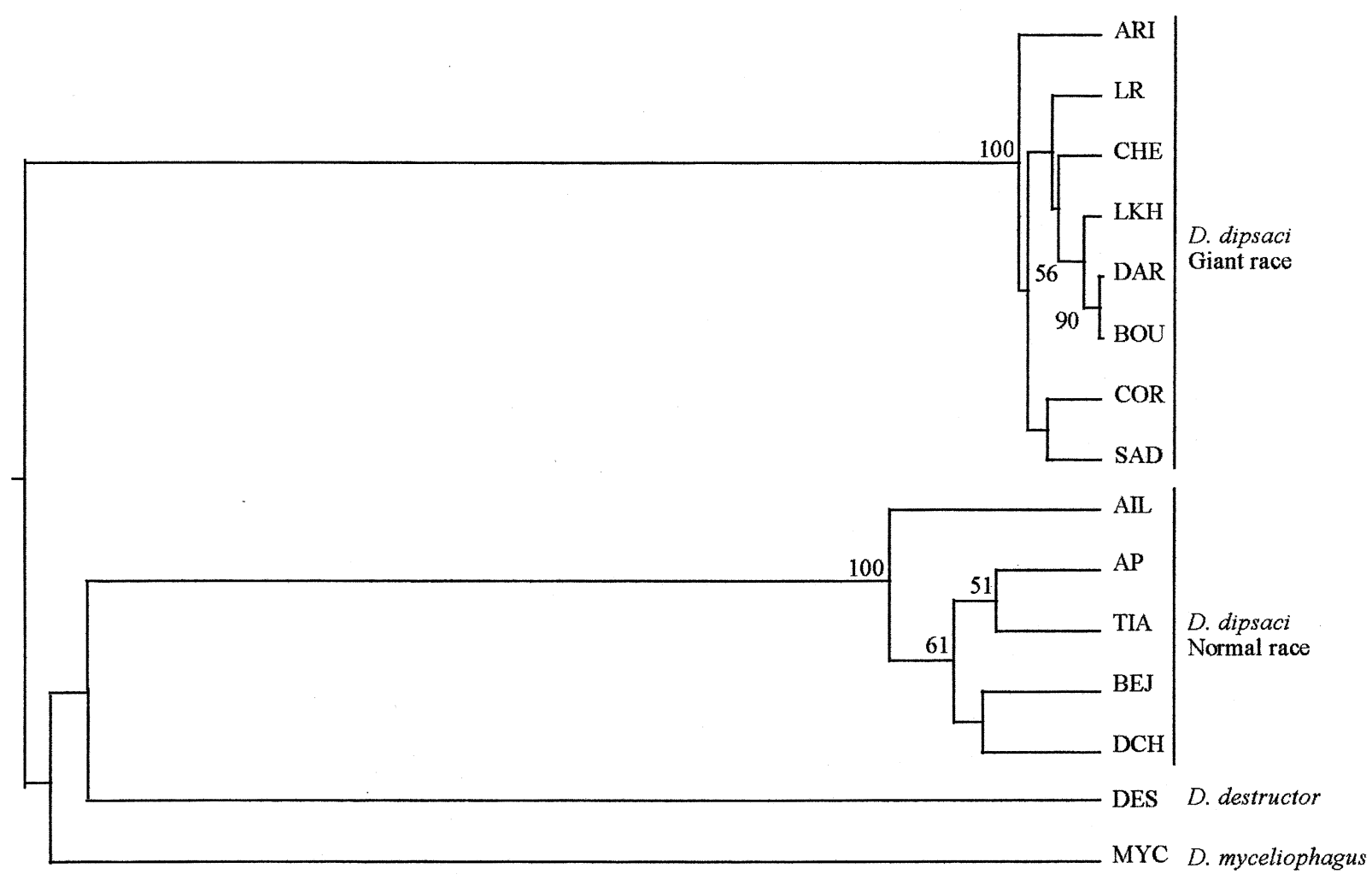

0.1

Fig. 2 UPGMA dendrogram showing estimated average genetic distances among different Ditylenchus species based on polymorphism generated by RAPD. This dendrogram was built using 124 polymorphic bands produced with 13 random primers. Average linkage cluster analysis was performed on the $(1-S)$ values. Bootstrap values $(\%)$ based on 1000 resamplings are given on appropriate clusters, when $>50 \%$. 
not observed using RFLP-ITS methods (Wendt et al., 1993). Shared fragments within the normal and giant populations associated with $V . f a b a$ ranged from 84 to $91 \%$ (average $85.9 \%$ ) and from 91 to $100 \%$ (average 94.9\%), respectively. This greater variation within the normal group than within the giant group could be explained by a larger host range among the normal populations. In contrast, coefficients of variation of the body size within the normal and the giant populations were similar. The low level of intraspecific polymorphism is in good agreement with RAPD studies performed on other plant-parasitic nematodes, e.g. Radopholus similis (Hahn et al., 1994), Globodera spp. (Folkertsma et al., 1994) or Heterodera avenae (López-Braña et al., 1996). In addition, no strong correlation could be found between the tree topology and the geographical origin of the populations as Hahn et al. (1996) pointed out for $R$. similis. Only the four giant Moroccan populations are clustered together.

The main method for controlling $D$. dipsaci is crop rotation, but the existence of races with differential host preferences makes this strategy difficult to apply in practice. Therefore, it is obvious that accurate identification of populations is essential in order to design an efficient crop rotation programme. For that purpose, a practical technique for a rapid and reliable identification of host races of $D$. dipsaci is necessary. As RAPD analysis yielded markers specific for the giant and normal races attacking faba bean, and also because polymorphism was observed between populations of both groups, it is suggested that this technique could be a powerful tool for rapid identification of $D$. dipsaci races and/or populations, as only one amplification in standardized reaction conditions is required. In preliminary experiments, attempts were made to use this method to identify single nematodes. Although variability occurred between samples, specific markers identical to those already observed by amplification of genomic DNA were produced (data not shown). Therefore RAPD may be useful to characterize the genotype from single Ditylenchus individuals as suggested for other organisms (Hadrys et al., 1992).

More extensive sampling of species and populations is required to confirm the informative value of the specific and subspecific clusters detected in this study, and more investigations are needed to select the best experimental conditions (primer combinations, number of individuals, etc.) to be used in routine analysis, but the RAPD approach appears more than promising for diagnostic purposes within the Ditylenchus genus.

\section{Acknow ledgements}

We thank F. Abbad Andaloussi, M. Kharrat, S. Sellami and E. Panchaud-Mattei for supplying original populations of $D$. dipsaci or D. myceliophagus and the anonymous reviewers for their comments on the manuscript and additional statistical analysis. This research is part of the GRAM programme (Groupe de Recherches Agronomiques Mediterranéen) concerning food legumes supported by the INRA Direction des Relations Internationales (M. Larbier).

\section{References}

AIT IGHIL, M. 1983. Variabilité physiologique de deux races, normale et géante, de Ditylenchus dipsaci (Kühn) Fil. (Nematoda: Tylenchida) parasite de Vicia faba L. Thesis, ENSA Rennes, Université de Rennes I.

BARRAClOUgh, R. AND BlACKITH, R. E. 1962. Morphometric relationships in the genus Ditylenchus. Nematologica, 8, 51-58.

CAUbel, G. AND LEClerCQ, D. 1989a. Vicia faba lines resistant to the giant race of stem nematode (Ditylenchus dipsaci (Kühn) Fil.). Fabis Newsletter, 25, 45-48.

CAUBEL, G. AND LECLERCQ, D. 1989b. Estimation de la résistance à la race géante de Ditylenchus dipsaci par les symptômes chez la féverole (Vicia faba L.). Nematologica, 35, 216-224.

CAYrol, J. C. 1970. Contribution à l'étude de la biologie de Ditylenchus myceliophagus Goodey, 1958, nématode édaphique mycétophage. Rev. Ecol. Biol. Sol, 3, $331-350$.

DEBRAY, F. AND MAUPAS, E. 1896. Tylenchus devastatrix (Kühn) et la maladie vermiculaire des fèves en Algérie. Algérie agricole, 1-53.

FELSENSTEIN, J. 1985. Confidence limits on phylogenies: an approach using the bootstrap. Evolution, 39, 783-791.

FelsensteIn, J. 1993. PHYLIP Phylogeny Inference Package, v. 3.5c. Distributed by the author. Department of Genetics, University of Washington, Seattle, WA.

FOLKERTSMA, R. T., ROUPPE VAN DER VOORT, J. N. A. M., VAN GENT-PELZER, M. P. E., D. E. GROOT, K. E., VAN DEN BOS, W. J. R., SCHOTS, А. ET AL. 1994. Inter and intraspecific variation between populations of Globodera rostochiensis and G. pallida revealed by Random Amplified Polymorphic DNA. Phytopathology, 84, 807-811.

GIBBINS, L. N. AND GRANDISON, G. s. 1968. An assessment of serological procedures for the differentiation of the biological races of Ditylenchus dipsaci. Nematologica 14, 184-188.

GOODEy, T. 1963. Soil and Freshwater Nematodes. Revised by J. B. Goodey. Methuen, London.

HADRYS, H., BALICK, M. AND SCHIERWATER, B. 1992. Applications of random amplified polymorphic DNA (RAPD) in molecular ecology. Mol. Ecol., 1, 55-63.

HAHN, M. L., BURROWS, P. R., GNANAPRAGASAM, N. C., BRIDGE, J., VINES, N. J. AND WRIGHT, D. J. 1994. Molecu- 
lar diversity amongst Radopholus similis populations from Sri Lanka detected by RAPD analysis. Fundam. appl. Nematol., 17, 275-281.

HAHN, M. L., BURROWS, P. R. AND WRIGHT, D. J. 1996. Genomic diversity between Radopholus similis populations from around the world detected by RAPD-PCR analysis. Nematologica, 42, 537-545.

HOOPER, D. J. 1984. Observations on stem nematode, Ditylenchus dipsaci, attacking field beans, Vicia faba. Rothamsted Exp. Station Report, 1983, 239-260.

HUSSEY, R. S. AND KRUSBERG, L. R. 1971. Disc-electrophoretic patterns of enzymes and soluble proteins of Ditylenchus dipsaci and D. triformis. J. Nematol., 1, 79-84.

JANSSEN, G. J. W. 1994. The relevance of races in Ditylenchus dipsaci (Kühn) Filipjev, the stem nematode. Fundam. appl. Nematol., 17, 469-473.

LADIGYNA, N. M. 1982. Biological races, karyotypes and hybridization. In: Gubina, V. G (ed.) Plants and Soil Nematodes: Genus Ditylenchus, pp. 69-86. Nauka, Moscow (in Russian).

LÓPEZ-BrAÑA, I., ROMERO, M. D. AND DELIBES, A. 1996. Analysis of Heterodera avenae populations by the random amplified polymorphic DNA technique. Genome, 39, 118-122.

NEI, M. AND LI W.-H. 1979. Mathematical model for studying genetic variation in terms of restriction endonucleases. Proc. Natl. Acad. Sci. U.S.A., 76, 5269-5273.

PALMER, H. M., ATKINSON, H. J. AND PERRY, R. N. 1991. The use of DNA probes to identify Ditylenchus dipsaci. Rev. Nématol., 14, 625-628.

SAMBROOK, J., FRITSCH, E. F. AND MANIATIS, T. 1989.
Molecular Cloning: A laboratory manual, 2nd edn. Cold Spring Harbor Laboratory Press, Cold Spring Harbor, New York.

SAS INSTITUTE (EDS). 1988. SAS/STAT User's Guide, release 6.03 edn. SAS Institute, Cary, NC.

SIKORA, R. A. AND GRECO, N. 1990. Nematode parasites of food legumes. In: Luc, M., Sikora, R. A. and Bridge, J. (eds) Plant Parasitic Nematodes in Subtropical and Tropical Agriculture, pp. 181-235. CAB International, London.

STURHAN, D. 1971. Biological races. In: Zuckerman, B. M., Mai, W. F. and Rhode, R. A (eds) Plant Parasitic Nematodes, pp. 51-71. Academic Press, New York.

STURHAN, D. 1983. The use of the subspecies and the superspecies categories in nematode taxonomy. In: Stone, A. R., Platt, H. M. and Khalil, L. F. (eds) Concepts in Nematode Systematics, pp. 41-53. Academic Press, New York.

STURHAN, D. AND BRZESKI, M. 1991. Stem and bulb nematodes, Ditylenchus spp. In: Nickle, W. R (ed.) Manual of Agricultural Nematology, pp. 423-464. Marcel Dekker, New York.

TRIANTAPHYllou, A. C. AND hirschmann, H. 1980. Cytogenetics and morphology in relation to evolution and speciation of plant-parasitic nematodes. Ann. Rev. Phytopathol., 18, 333-359.

WENDT, K. R., VRAIN, T. C. AND WEBSTER, J. M. 1993. Separation of three species of Ditylenchus and some host races of $D$. dipsaci by restriction fragment length polymorphism. J. Nematol., 25, 555-563. 